\title{
The BRCA1 exon 13 duplication: clinical characteristics of 22 families in Northern Sweden
}

\author{
Christina Edwinsdotter Ardnor ${ }^{1}\left[\right.$ [ $\cdot$ Anna Rosén ${ }^{1} \cdot$ Ingrid Ljuslinder $^{1} \cdot$ Beatrice Melin ${ }^{1}$
}

Published online: 22 August 2018

(c) The Author(s) 2018

\begin{abstract}
The clinical management of BRCA1/2 mutation carriers requires accurate cancer risk estimates. Cancer risks vary according to type and location of the mutation and since there is limited information about mutation-specific cancer risks, genotypephenotype correlation studies are needed. This is a report of 22 families with the same mutation, BRCAl duplication exon 13 , a mutation that is found world-wide, with the objective to describe the cancer history found in these families. We studied 69 confirmed carriers, 53 women and 16 men, and additionally 29 women who were clinically expected carriers. Among the confirmed carriers, 27 women (51\%) were diagnosed with breast cancer, $10(19 \%)$ with ovarian cancer, $5(9 \%)$ with breast and ovarian cancer and 17 (32\%) without cancer. Nine women (17\%) with breast cancer were 35 years or younger at diagnose. Also, two cases of early onset colon cancer were found, and 37,5\% of the male carriers were diagnosed with prostate cancer. These data may have implications for risk assessment and cancer prevention decision making for carriers of the BRCAl duplication exon 13 mutation.
\end{abstract}

Keywords $B R C A 1 \cdot B R C A 1$ ins6kbEx $13 \cdot$ Breast cancer $\cdot$ Ovarian cancer $\cdot$ Prostate cancer $\cdot$ Colon cancer

\section{Introduction}

A germline pathological variant in the $B R C A 1$ or $B R C A 2$ genes confers to a high lifetime risk of both breast and ovarian cancer, and when such a variant is confirmed, adequate strategies for surveillance can be recommended. Surveillance includes screening with mammography and/or MRI of the breast, and risk-reducing surgery-mastectomy and/ or salpingo-oophorectomy.

Counselling families about their cancer risk can be challenging due to wide-ranging risk estimates. In 1995, Easton et al. [1] reported an estimated breast cancer risk for BRCA1 carriers of $>80 \%$ while more recent data estimate an average

Christina Edwinsdotter Ardnor

christina.edwinsdotter@onkologi.umu.se

Anna Rosén

anna.rosen@umu.se

Ingrid Ljuslinder

Ingrid.ljuslinder@vll.se

Beatrice Melin

Beatrice.melin@umu.se

1 Department of Radiation Sciences, Oncology, Umeå University, Umeå, Sweden cumulative risk by age 70 years to be $60 \%$ for breast cancer, $59 \%$ for ovarian cancer and $83 \%$ for contralateral breast cancer [2]. However, it has also been shown that the cancer risk varies by type and location of BRCA1 mutation [3].

In Northern Sweden, we note a high proportion of a specific mutation in BRCA1, duplication exon 13. In this report, we describe the phenotype of this specific $B R C A l$ variant. This mutation is a large genomic rearrangement, the $4:$ th most common BRCAl mutation in North America [4] and comprise for $9 \%$ of $B R C A 1$ mutations in UK [5]. It has also been found in other geographically diverse populations, such as Australia, Belgium, Canada, Italy, Norway [5, 6]. We herein describe clinical data on 98 individuals from 22 different families.

\section{Materials and methods}

At the cancer genetic clinic at the University Hospital of Umeå, we identified 22 families during 1998-2017, with at least one confirmed carrier of the BRCAldup ex13, also known as $B R C A 1$ ins $6 \mathrm{kbEx} 13$ or according to HGVS: C.4186-1787_4357+4122dup. These 22 families comprise $15 \%$ of all BRCA1 mutations registered at our clinic. 
Within the 22 families there was 91 confirmed mutation screened carriers or obligate carriers. To give a comprehensive picture of the clinical presentation of the families we also included 29 clinically expected carriers from previous generations where no blood sample was available to ascertain mutation status, rendering a total of 120 individuals.

The definition of a clinically expected carrier was women with a verified diagnose of breast or ovarian cancer where at least one family member was a confirmed carrier of the BRCAIdupex 13 .

In the total group of 120 individuals, 71 were deceased, and these individuals were included without contacting relatives for informed consent. To obtain further clinical information about the breast and ovarian cancer cases from the regional quality registry and to verify additional cancer diagnoses by the Swedish Cancer Registry we proceeded to contact the 49 living individuals. 11 were excluded when their addresses could not be ascertained. The 38 remaining individuals were contacted for written informed consent, and the 11 who failed to answer were excluded. After the exclusion, the confirmed carrier group consisted of 69 individuals, and in the total group also including clinically expected carriers, 98 individuals remained.

For families investigated from 2008 to 2017 the BOADICEA calculated mutation probability prior to mutation screening was obtained. For families investigated prior to 2008, we supplemented with calculation of mutation probability according to the information known in the family at time of mutation screening, using BOADICEA WEB APPLICATION version 3.

The Regional Ethical Review Board in Umeå approved the study.

\section{Results}

To give a comprehensive picture of the clinical presentation of the families, we chose to present the number of cancer diagnoses per family, including age at diagnose, from the total group of all 120 individuals, both verified carriers, obligate carriers and clinically expected carriers, in Table 1. We then present more detailed data obtained after informed consent in Table 2.

Using BOADICEA to calculate Mutation probabilities before mutation screening revealed a broad range estimate from 3.3 to $98.5 \%$ (Table 1).

Cancer characteristics for both groups are presented in Table 2. Among confirmed carriers, 27 (51\%) of the women were diagnosed with breast cancer, and nine of them (17\%) were 35 or younger at first breast cancer diagnose, with two cases in very early age, 24 and 28 years. When excluding five individuals with both breast and ovarian cancer, 8 out of $22(36 \%)$ died due to breast cancer (bc), the mean time between bc diagnose and death was 3.9 years. In many cases, especially in the group including clinically expected carriers, information about Estrogen receptor status or Her2 receptor status was missing, but all histopathological types of breast cancer were present. All individuals who were diagnosed with both ovarian and breast cancer had their breast cancer diagnosed two years or more before their ovarian cancer.

Of the women in the confirmed carrier group $(n=53)$, $17(32 \%)$ had no cancer diagnose. 18 (34\%) died of cancer; eight of breast cancer, eight of ovarian cancer and two from colon cancer. The two female carriers with colon cancer came from two different families and were diagnosed at age 42 and 47, and both died within one year of diagnose. Among male carriers $(n=16)$, six $(37,5 \%)$ were diagnosed with prostate cancer and there were also two cases of lung cancer at age 63 and 69, and one case of cancer arising from Papilla Vateri at age 52 (Table 2). Two families are illustrated with pedigrees, one including colon cancer (Fig. 1), and one with prostate cancer (Fig. 2).

Since clinical data was known in the families, we could assess that the exclusion of the individuals who we could not reach to ask for informed consent, and the ones who failed to answer, (in total 22 individuals), did not markedly influence the results.

\section{Discussion}

This is, to our knowledge, the largest cohort of BRCAl duplication exon 13 mutation carriers. 19 of the 22 families originate from Northern Sweden, but from different geographical areas in this region. Our findings are consistent with the data from James et al. that showed that large genomic rearrangements in BRCAl are associated with an increased risk of high risk features, such as bilateral breast cancer, diagnosis $<40$ years and ovarian cancer [7]. Our results show a high proportion of early onset breast cancer, and since the best cost-benefit of prophylactic mastectomy is shown when surgery is performed before first breast cancer diagnose this might be worth considering when counselling women with this mutation.

The elevated risk for prostate cancer in $B R C A 2$ carriers is well known. However, a recent study of 1072 BRCA1/2 mutation carriers by Mersch et al. did not show an increased prostate cancer risk for $B R C A 1$ mutation carriers [8] and there is to date no recommendation for prostate cancer screening in this group. Interestingly, we found that $37,5 \%$ of the male carriers in our cohort were diagnosed with prostate cancer in comparison to the expected $17 \%$ in the Swedish population [9]. This might suggest that in BRCAl ins6kbEx 13 families' male carriers should be recommended PSA screening according to practice in families with hereditary elevated risk. 
Table 1 Cancer incidence in families with BRCAlins6kbEx13 mutation

\begin{tabular}{|c|c|c|c|c|c|}
\hline Family & $\begin{array}{l}\text { No of individuals, confirmed } \\
\text { and expected carriers } \\
\mathrm{N}=120^{*}\end{array}$ & $\begin{array}{l}\text { Breast cancer, no of diagno- } \\
\text { ses, age at onset (year) }\end{array}$ & $\begin{array}{l}\text { Ovarian cancer, no of diag- } \\
\text { noses, age at onset (year) }\end{array}$ & $\begin{array}{l}\text { Other cancer types, age at } \\
\text { onset (year) }\end{array}$ & $\begin{array}{l}\text { BOADI- } \\
\text { CEA } \\
\text { brca1/ } \\
\text { brca2** } \\
(\%)\end{array}$ \\
\hline 1 & 2 & $\begin{array}{l}1 \\
50\end{array}$ & 0 & Prostate, 62 & 3.3 \\
\hline 2 & 4 & $\begin{array}{l}\mathbf{3} \\
44,50,58\end{array}$ & 0 & Parathyroid, 38 & 6.4 \\
\hline 3 & 2 & $\begin{array}{l}2 \\
44,52\end{array}$ & 0 & Prostate, 73 & 6.8 \\
\hline 4 & 1 & $\begin{array}{l}\mathbf{2} \\
31,47\end{array}$ & 0 & 0 & 7.0 \\
\hline 5 & 4 & $\begin{array}{l}1 \\
53\end{array}$ & $\begin{array}{l}1 \\
48\end{array}$ & Squamous cell cancer, 84 & 10.2 \\
\hline 6 & 7 & $\begin{array}{l}\mathbf{2} \\
31,42\end{array}$ & 0 & Colon 47 & 20.1 \\
\hline 7 & 5 & $\begin{array}{l}\mathbf{3} \\
35,46,55\end{array}$ & $\begin{array}{l}1 \\
68\end{array}$ & 0 & 34.8 \\
\hline 8 & 5 & $\begin{array}{l}\mathbf{4} \\
37,40,42,43\end{array}$ & $\begin{array}{l}1 \\
48\end{array}$ & 0 & 46.7 \\
\hline 9 & 3 & $\begin{array}{l}\mathbf{5} \\
31,43,51,59,70\end{array}$ & 0 & 0 & 49.2 \\
\hline 10 & 6 & $\begin{array}{l}\mathbf{2} \\
28,46\end{array}$ & $\begin{array}{l}1 \\
48\end{array}$ & $\begin{array}{l}\text { Prostate, } 58 \\
\text { Lung/bronch, } 69 \\
\text { Prostate, } 74\end{array}$ & 60.7 \\
\hline 11 & 3 & $\begin{array}{l}\mathbf{3} \\
43,48,63\end{array}$ & $\begin{array}{l}2 \\
63,70\end{array}$ & 0 & 60.8 \\
\hline 12 & 10 & $\begin{array}{l}\mathbf{2} \\
31,47\end{array}$ & $\begin{array}{l}1 \\
38\end{array}$ & $\begin{array}{l}\text { Colon, } 42 \\
\text { Papilla Vateri, } 52\end{array}$ & 63.0 \\
\hline 13 & 9 & $\begin{array}{l}\mathbf{4} \\
38,39,45,53\end{array}$ & $\begin{array}{l}\mathbf{2} \\
51,55\end{array}$ & Lung/bronch, 63 & 65.4 \\
\hline 14 & 2 & $\begin{array}{l}\mathbf{2} \\
28,53\end{array}$ & $\begin{array}{l}1 \\
58\end{array}$ & 0 & 71.0 \\
\hline 15 & 9 & $\begin{array}{l}\mathbf{6} \\
31,42,42,43,45,48\end{array}$ & 0 & 0 & 71.4 \\
\hline 16 & 4 & 0 & $\begin{array}{l}\mathbf{4} \\
49,67,75,78\end{array}$ & 0 & 73.4 \\
\hline 17 & 3 & $\begin{array}{l}\mathbf{4} \\
24,34,59,69\end{array}$ & 0 & Lung/bronch, 56 & 79.7 \\
\hline 18 & 5 & $\begin{array}{l}\mathbf{2} \\
32,35\end{array}$ & $\begin{array}{l}2 \\
50,55\end{array}$ & Pancreas, 69 & 87.3 \\
\hline 19 & 19 & $\begin{array}{l}7 \\
34,42,50,51,58,61,65\end{array}$ & $\begin{array}{l}\mathbf{3} \\
44,62,62\end{array}$ & $\begin{array}{l}\text { Cervix, } 25 \\
\text { Cervix, } 41\end{array}$ & 89.4 \\
\hline 20 & 5 & $\begin{array}{l}\mathbf{6} \\
43,47,49,51,53,55\end{array}$ & $\begin{array}{l}1 \\
50\end{array}$ & 0 & 91.0 \\
\hline 21 & 9 & $\begin{array}{l}1 \\
48\end{array}$ & $\begin{array}{l}1 \\
41\end{array}$ & $\begin{array}{l}\text { Prostate, } 57 \\
\text { Prostate, } 69\end{array}$ & 91.2 \\
\hline 22 & 3 & $\begin{array}{l}1 \\
56\end{array}$ & $\begin{array}{l}3 \\
40,46,58\end{array}$ & 0 & 98.5 \\
\hline
\end{tabular}

Bold numbers indicate number of diagnoses of breast cancer or ovarian cancer in the families respectively

Number of confirmed cancer diagnoses per family, including age at onset, and BOADICEA estimation of mutation probability prior to mutation screening

*All individuals before exclusion

**Estimation of mutation probability prior to screening calculated with BOADICEA WEB APPLICATION version 3 . Sensitivity 0.9 for both BRCA1 and BRCA2 and using Swedish cancer incidence rates. Results for BRCA1 and BRCA2 combined 
Table 2 Characteristics of BRCAins6kbEx13-carriers $(n=69)$ and pooled data of BRCAins6kbEx13-carriers and clinically expected carriers (expected carriers $n=29$, in total $n=98$ )

\begin{tabular}{|c|c|c|}
\hline & $\begin{array}{l}\text { BRCA1ins6k- } \\
\text { bEx13 carrier } \\
\text { No. }=69\end{array}$ & $\begin{array}{l}\text { Confirmed carriers includ- } \\
\text { ing clinically expected } \\
\text { carriers } \\
\text { No. }=98\end{array}$ \\
\hline Women & 53 & 82 \\
\hline Men & 16 & 16 \\
\hline \multicolumn{3}{|l|}{ Breast cancer } \\
\hline No of women with BC diagnose, No. (\%) & $27(51)$ & $43(52)$ \\
\hline No of men with BC diagnose, No & 0 & 0 \\
\hline No of Breast cancer diagnoses, No & 33 & 53 \\
\hline Bilateral BC, No. (\%) & $3(6)$ & $7(9)$ \\
\hline Two BC diagnoses, same side, No. (\%) & $3(6)$ & $3(4)$ \\
\hline Mean age at first BC diagnose, year (range) & $42,4(24-65)$ & $45,0(24-69)$ \\
\hline TNBC, *No. (\%) & $10(30)$ & $11(21)$ \\
\hline ER pos, Her2 neg BC, No & 1 & 2 \\
\hline ER pos, Her2 pos BC, No & 4 & 4 \\
\hline ER neg, Her2 pos BC, No & 2 & 2 \\
\hline BC, ER or Her2 receptor status not known, No. (\%) & $16(48)$ & $34(64)$ \\
\hline \multicolumn{3}{|l|}{ Ovarian cancer } \\
\hline No of women with ovarian cancer diagnose, No (\%) & $10(19)$ & $24(29)$ \\
\hline Mean age at ovarian cancer diagnose, year (range) & $57.4(41-70)$ & $55.2(38-78)$ \\
\hline Ovary, serous, No & 5 & 9 \\
\hline Ovary, endometrioid, No & 1 & 1 \\
\hline Ovary, adenocarcinoma, NOS, No & 2 & 2 \\
\hline Ovary, type not known, No & 2 & 12 \\
\hline \multicolumn{3}{|l|}{ Both Breast and Ovarian cancer } \\
\hline No of individuals with both diagnoses (\%) & $5(9)$ & $7(9)$ \\
\hline \multicolumn{3}{|l|}{ Other cancer diagnoses among confirmed carriers } \\
\hline No of other cancer diagnoses (female/male) & $14(5 / 9)$ & \\
\hline Female, cervix uteri & 2 & \\
\hline Female, colon (age, year) & $2(42.47)$ & \\
\hline Male, prostate (range, year) & $6(57-74)$ & \\
\hline Male, lung/bronch & 2 & \\
\hline Male, Papilla Vateri & 1 & \\
\hline
\end{tabular}

*TNBC Triple Negative Breast Cancer
When counselling families, the mutation probability tool BOADICEA has become a valuable asset. Our families show a wide range of mutation probability prior to screening. Therefore, BOADICEA should be seen as a tool for support but if there is limited information due to a small pedigree or loss of relevant information, mutation screening in a breastovarian cancer family should be recommended in spite of low BOADICEA estimates.

We found two women with early onset colon cancer, both with fatal outcome. When reviewing colorectal cancer risk in 7015 female BRCAl and BRCA2 mutation carriers, Sopik et al. found a significant fivefold increased risk of colorectal cancer for female BRCAl mutation carriers under age 50 (Sopik et al. [10]). Since colorectal cancer can be prevented through colonoscopy screening and removal of adenomatous polyps the authors proposed that all female BRCAl mutation carriers should be offered colonoscopy at 3- to 5-year intervals between the ages of 40 and 50 years. As colon cancer is rarely occurring in the families this might be a too strong recommendation, but our data suggest that it may be relevant for in example the $B R C A 1$ ins $6 \mathrm{kbEx} 13$ mutation. In conclusion, we here present a large case series of $B R C A 1$ dup ex13 mutation carriers that present with early onset breast and ovarian cancer, but we also see a higher than expected rate of prostate and early onset colorectal cancer implying that additional surveillance may be necessary for carriers of this mutation. 


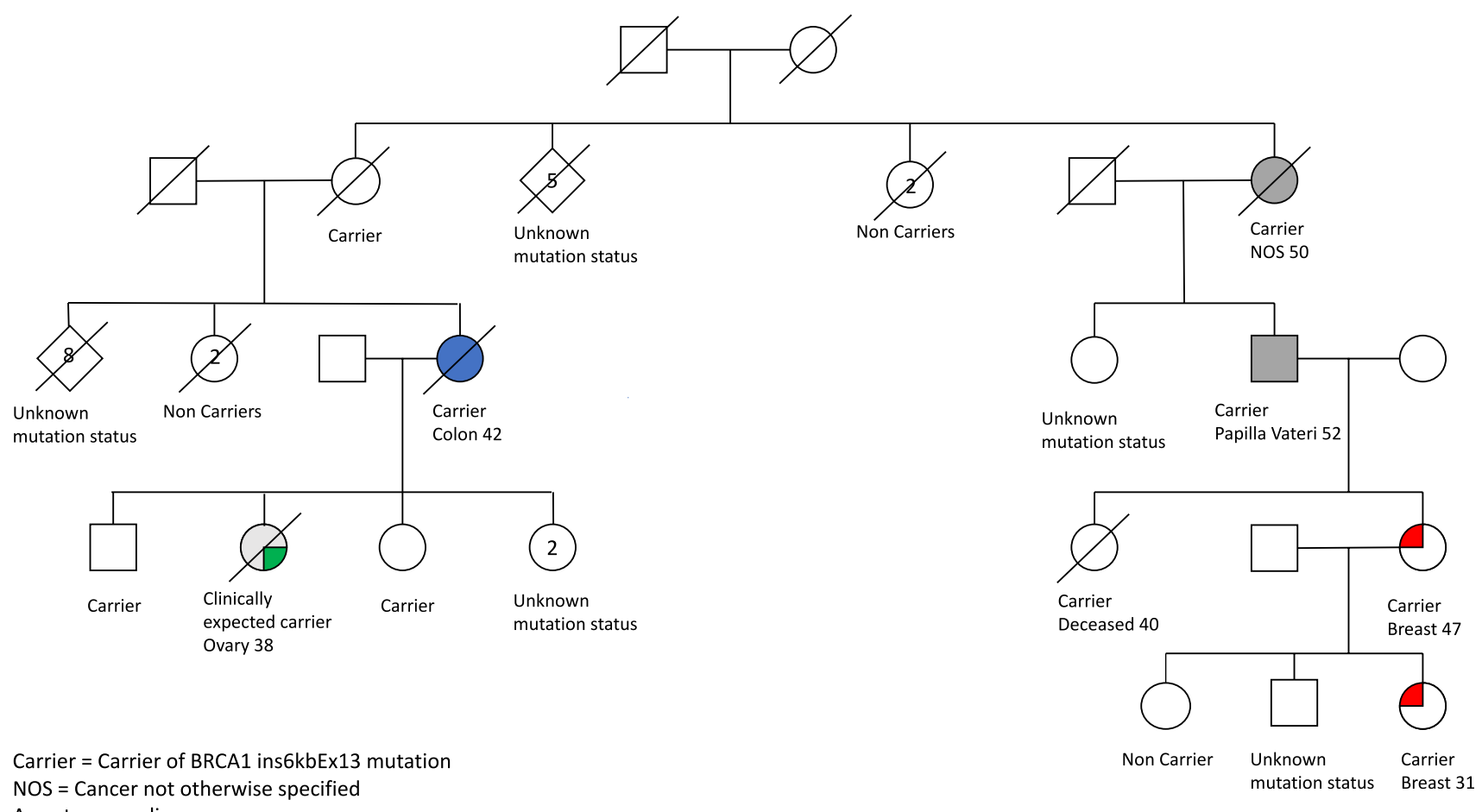

Fig. 1 Family with colon cancer, illustrated after exclusion

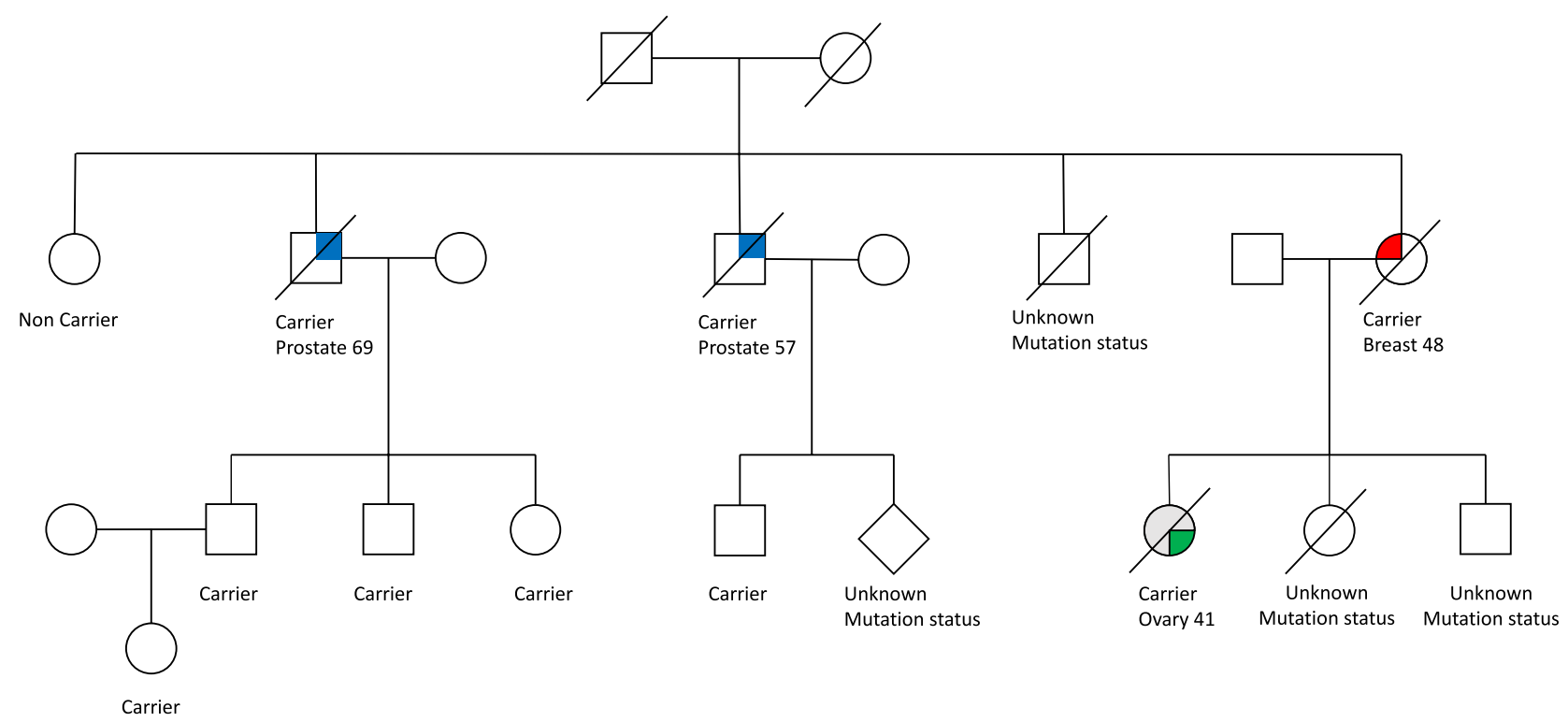

Carrier $=$ Carrier of BRCA1 ins6kbEx13 mutation

Age at cancer diagnose

Fig. 2 Family with prostate cancer, illustrated after exclusion

Acknowledgements We would like to thank the participating patients. Financial support for manuscript preparation was provided by a regional agreement between Umeå University and Västerbotten County Council (ALF) and was supported by grants from Umeå
University Hospital, and Acta Oncologica through Royal Swedish Academy of Science (BM salary). Carin Nylander and Lena Lundkvist are acknowledged for their contribution of collecting data. 


\section{Compliance with ethical standards}

Conflict of interest The authors declare that they have no conflict of interest.

Open Access This article is distributed under the terms of the Creative Commons Attribution 4.0 International License (http://creativeco mmons.org/licenses/by/4.0/), which permits unrestricted use, distribution, and reproduction in any medium, provided you give appropriate credit to the original author(s) and the source, provide a link to the Creative Commons license, and indicate if changes were made.

\section{References}

1. Easton DF, Ford D, Bishop DT (1995) Breast and ovarian cancer incidence in BRCA1-mutation carriers. Breast Cancer Linkage Consortium. Am J Hum Genet 56(1):265-271

2. Mavaddat N, Antoniou AC, Easton DF, Embrace (2013) Cancer risks for BRCA1 and BRCA2 mutation carriers: results from prospective analysis of EMBRACE. J Natl Cancer Inst 105(11):812822. https://doi.org/10.1093/jnci/djt095

3. Rebbeck TR, Andrulis I (2015) Association of type and location of BRCA1 and BRCA2 mutations with risk of breast and ovarian cancer. JAMA 313(13):1347-1361. https://doi.org/10.1001/ jama.2014.5985

4. Hendrickson BC, Judkins T, Ward BD, Eliason K, Deffenbaugh AE, Burbidge LA, Pyne K, Leclair B, Ward BE, Scholl T (2005)
Prevalence of five previously reported and recurrent BRCA1 genetic rearrangement mutations in 20,000 patients from hereditary breast/ovarian cancer families. Genes Chromosomes Cancer 43(3):309-313. https://doi.org/10.1002/gcc.20189

5. Janavicius R (2010) Founder BRCA1/2 mutations in the Europe: implications for hereditary breast-ovarian cancer prevention and control. EPMA J 1(3):397-412. https://doi.org/10.1007/s1316 7-010-0037-y

6. The exon 13 duplication in the BRCA1 gene is a founder mutation present in geographically diverse populations. The BRCA1 Exon 13 Duplication Screening Group (2000). Am J Hum Genet 67 (1):207-212

7. James PA, Sawyer S, Boyle S, Young MA, Kovalenko S, Doherty R, McKinley J, Alsop K, Beshay V, Harris M, Fox S, Lindeman GJ, Mitchell G (2015) Large genomic rearrangements in the familial breast and ovarian cancer gene BRCA1 are associated with an increased frequency of high risk features. Fam Cancer 14(2):287-295. https://doi.org/10.1007/s10689-015-9785-0

8. Mersch J, Jackson MA, Park M, Nebgen D, Peterson SK, Singletary C, Arun BK, Litton JK (2015) Cancers associated with BRCA1 and BRCA2 mutations other than breast and ovarian. Cancer 121(2):269-275. https://doi.org/10.1002/cncr.29041

9. Bratt O, Drevin L, Akre O, Garmo H, Stattin P (2016) Family history and probability of prostate cancer, differentiated by risk category: a nationwide population-based study. J Natl Cancer Inst 108 (10). https://doi.org/10.1093/jnci/djw110

10. Sopik V, Phelan C, Cybulski C, Narod SA (2015) BRCA1 and BRCA2 mutations and the risk for colorectal cancer. Clin Genet 87(5):411-418. https://doi.org/10.1111/cge.12497 